J. Clin. Chem. Clin. Biochem.

Vol. 24, 1986, pp. 375-378

(C) 1986 Walter de Gruyter \& Co. Berlin · New York

\title{
N-Acetylalanine Aminopeptidase Activity in Normal and Tumour Cells
}

\author{
By O. L. Schoenberger, H. Schwöbel and W. Ebert \\ Krankenhaus Rohrbach, Klinik für Thoraxerkrankungen, Heidelberg
}

(Received November 15, 1985/February 14, 1986)

Summary: The catalytic concentration of $\mathrm{N}$-acetylalanine aminopeptidase was determined in erythrocytes, polymorphonuclear leukocytes, lymphocytes, alveolar macrophages, human lung fibroblasts, human lung cancer cells, human umbilical vein endothelial cells, mice Leydig cells, rat tumour cells, and endothelial cells from hog and bovine lung. The catalytic concentration ranged from, $0.5 \pm 0.1 \mathrm{nU} /$ cell (erythrocytes) to $35 \mathrm{nU} /$ cell (rat tumour cell line B Sp 73 ASML). Almost all tumour cells showed higher activity levels. No activity was found in human plasma.

\section{$N$-Acetylalanin-aminopeptidase-Aktivität in normalen Zellen und in Tumorżellen}

Zusammenfassung: Die katalytische Konzentration von N-Acetylalanin-aminopeptidase bestimmten wir in Erythrocyten, polymorphkernigen Leukocyten, Lymphocyten, Alveolar-Makrophagen, menschlichen Lungenfibroblasten, menschlichen Lungentumorzellen, menschlichen Nabelschnurendothelzellen, Leydig-Zellen von Mäusen, Ratten-Tumorzellen und Endothelzellen aus Schweine- und Rinderlunge. Die katalytische Konzentration reichte von 0,5 $\pm 0,1 \mathrm{nU} /$ Zelle (Erythrocyten) bis $\mathrm{zu} 35 \mathrm{nU} /$ Zelle (Ratten Tumorzell-Linie B Sp 73 ASML). In fast allen Tumorzellen wurde eine erhöhte Aktivität gefunden. Keine Aktivität konnte im menschlichen Plasma nachgewiesen werden.

\section{Introduction}

$\mathrm{N}$-Acylamino acyl-peptide hydrolases (EC 3.4.19.1) have been found in different tissues of a variety of vertebrates $(1-10)$ and in $E$. coli $\mathrm{B}(3)$. Despite small differences in their biochemical properties, they have many characteristics in common, for example the high molecular weight of about 300000 Dalton, the optimal activity at around $\mathrm{pH} 8$, the sensitivity against sulphydryl blocking reagents, the lack of any effect of cations and the release of acylamino acids from peptides. The substrates specificity, however, is not exactly the same for all $\mathrm{N}$-acylamino acyl-peptide hydrolases. In a recently published paper, Jones \& Manning (10) pointed out that the pH-optimum can change, depending on the substrate; for example they obtained for the human erythrocyte enzyme a $\mathrm{pH}$ optimum of $\mathrm{pH} 8$ with $\mathrm{N}$-acetyl-alanine-p-nitroanilide as substrate, but with $\mathrm{N}$-acetyl-glutamate- $p$-nitroanilide as substrate the $\mathrm{pH}$-optimum was shifted to $\mathrm{pH} 6$.
We found that $\mathrm{N}$-acetylalanine-p-nitroanilide is a good substrate for the enzyme from human erythrocytes (8). In this publication we show that $\mathrm{N}$-acetylalanine aminopeptidase can be detected in many cells. The high activity of the enzyme permits a simple quantiative determination.

\section{Material and Methods ${ }^{1}$ )}

\section{Cells}

T- and B-lymphocytes and monocytes were a gift from Dr. Manke at our hospital. Alveolar macrophages were isolated from bronchial alveolar lavage in cooperation with Dr. Becker at our hospital. Mice Leydig cells were kindly provided by Prof. Merz, University of Heidelberg. Rat BDX BSp 73 AS and ASMĹ cell lines (11) were generously furnished by Prof. Paweletz of the German Cancer Research Centre in Heidelberg.

All other cells were isolated and cultured in our laboratory. Erythrocytes and polymorphonuclear leukocytes were isolated from fresh blood of a healthy donor by density centrifugation with a Percoll gradient according to Nees \& Fink (12).

1) Abbreviation: RPMI: Rosewell-Park-Memorial Institute 
The isolation of human cancer cells will be described in detail elsewhere (13). Briefly, human lung tumour pieces were minced and then usually digested with $1 \mathrm{~g} / \mathrm{l}$ collagenase (Worthington, Cat. No. LS 0004176; catalytic concentration: $180 \mathrm{U} / \mathrm{mg}$ ). After filtration through a nylon gauze (Schweizerische Seidengazefabrik, Zürich, Nybolt $81 / 2 \mathrm{XXX}-160$ ) the cells were seeded in culture flasks (Falcon, Heidelberg, Cat. No. 3024). RPMI-1640 (Seromed, Berlin, Cat. No. F-1215) containing $100 \mathrm{ml} / \mathrm{l}$ foetal calf serum (Seromed, S-0115), $100 \cdot 10^{3} \mathrm{U} / 1$ penicillin and 100 - $10^{3} \mathrm{U} / 1$ streptomycin (Gibco, Karlsruhe, Cat. No. 043-5140) and $2 \mathrm{mmol} / \mathrm{l}$ glutamine (Flow Laboratories, Meckenheim, Cat. No. 16-30-1-46) was used as medium for the tumour cells. A medium change was performed every other day. Usually after one week the adherent cells were harvested by treatment with $1.25 \mathrm{~g} / 1$ trypsin and $1.25 \mathrm{~g} / 1$ EDTA (both reagents were from Serva, Heidelberg; Cat. No. 37290 and Cat. No. 11280, respectively) solution in phosphate buffered saline. Essentially the same method was used for human lung fibroblasts.

To obtain endothelial cells, fresh bovine or hog lungs were perfused with $9 \mathrm{~g} / \mathrm{l}$ sodium chloride solution. A chymotrypsin/ EDTA solution ( $1 \mathrm{~g} / \mathrm{l} \alpha$-Chymotrase ${ }^{\circledR}$, Hasenclever, Bonn) was pumped through the perfusion tubes into the lung. The flow of the solution was then stopped, and after $5 \mathrm{~min}$ at $37^{\circ} \mathrm{C}$ the detached cells were collected, washed with RPMI-1640 (this time from Gibco, Cat. No. 048-2400, which has a different composition compared to RPMI-1640 purchased from Seromed) containing penicillin and streptomycin (each $100 \cdot 10^{3}$ $\mathrm{U} / \mathrm{l}$ ), and supplemented with $200 \mathrm{ml} / \mathrm{l}$ foetal calf serum. The cells were cultured in the same medium.

Endothelial cells from human umbilical vein were isolated in the same way.

The cells were identified histologically.

For the investigation of whether plasma contains $\mathrm{N}$-acetylalanine aminopeptidase activity, blood was withdrawn into tubes with and without beads $\left(\mathrm{NH}_{4}\right.$-Heparin Monovette and EDTA K Monovette, Sarstedt, Nümbrecht).

\section{Cell lysis}

Cells were washed twice with $10 \mathrm{ml} 9 \mathrm{~g} / \mathrm{l}$ sodium chloride solution. After counting the cell number in a haemocytometer and after checking the viability of the cells with trypan blue, the cell suspension (usually $10^{7}$ cells $/ 10 \mathrm{ml}$ ) was lysed by short ultrasonic treatment with a Labsonic 1510 (Braun, Melsungen) at $40 \mathrm{~W}$ for 30 to $60 \mathrm{~s}$. The membranes were removed by centrifugation at $25000 \mathrm{~g}$ and the supernatant was used to measure enzymatic activity. In order to be sure that all cells were disrupted, the pellet was again ultrasonicated. Usually less than $5 \%$ of the activity emerged, i. e. $95 \%$ of the cells were lysed by the first ultrasonic treatment.

\section{Activity assay}

The $\mathrm{N}$-acetylalanine aminopeptidase assay was performed in $0.1 \mathrm{~mol} / 1 \mathrm{Tris} / \mathrm{HCl}$ buffer, $\mathrm{pH} 8.3$ containing $0.01 \mathrm{~mol} / 1$ calcium chloride and $0.05 \mathrm{ml} / \mathrm{l}$ Triton X-100 at $25^{\circ} \mathrm{C}$. A $200 \mu \mathrm{l} \mathrm{sample}$ was added to $795 \mu \mathrm{l}$ buffer in a $1 \mathrm{ml}$ cuvette. The reaction was started with $5 \mu \mathrm{l} \mathrm{N}$-acetyl- $L$-alanine-p-nitroanilide $(40 \mathrm{~g} / 1$ dimethylsulphoxide; the substrate was purchased from Serva, Cat. No. 10160). The release of $p$-nitroaniline was measured at $405 \mathrm{~nm}$ with an Uvikon 810 (Kontron, Eching). The activity was calculated using $\varepsilon=962 \mathrm{~m}^{2} / \mathrm{mol}$ (14).

For the analysis of the haemolysate, the sample volume was reduced to $100 \mu$ l, because of the strong absorbance of haemoglobin at $405 \mathrm{~nm}$.

\section{Results}

$\mathrm{N}$-acetylalanine aminopeptidase activity in human blood cells

In a previous paper (8), which deals with the isolation and some characteristics of $\mathrm{N}$-acetylalanine aminopeptidase from human erythrocytes, we calculated that erythrocytes contain $0.6-0.75 \mathrm{nU} /$ cell $\mathrm{N}$-acetylalanine aminopeptidase activity, but this calculation was not based on an exact cell number. The amount of enzyme determined in the present study was 0.5 $\pm 0.1 \mathrm{nU} /$ cell (tab. 1). In addition to the determination of the amount of $\mathrm{N}$-acetylalanine aminopeptidase in erythrocytes, the enzymic activity was also measured in different types of white blood cells (tab. 1). T-lymphocytes showed a slightly higher activity than erythrocytes and B-lymphocytes, and monocytes had twice as much activity as red blood cells. In the case of polymorphonuclear leukocytes the activity was almost four times that in erythrocytes. The differences were statistically significant $(\mathrm{p}<0.05)$ in a Wilcoxon test $(15)$.

Tab. 1. N-acetylalanine aminopeptidase activity in human blood cells. Values are means $\pm S$. D. of the number of cell preparations. Ërythrocytes were only isolated four times, but 15 dilutions were made from each preparation; in this way we obtained 60 samples for the determination of $\mathrm{N}$-acetylalanine aminopeptidase activity.

The number of viable cells exceeded $10^{6}$ in all preparations.

\begin{tabular}{lll}
\hline & \multicolumn{1}{l}{ Catalytic concentration } \\
$(\mathrm{nU} /$ cell $)$ & \\
\hline Erythrocytes & $0.5 \pm 0.1$ & $(\mathrm{n}=60)$ \\
T-lymphocytes & $0.75 \pm 0.18$ & $(\mathrm{n}=9)$ \\
B-lymphocytes & $1.3 \pm 0.3$ & $(\mathrm{n}=5)$ \\
Monocytes & $0.98 \pm 0.17$ & $(\mathrm{n}=7)$ \\
Polymorphonuclear leukocytes & $1.9 \pm 0.7$ & $(\mathrm{n}=6)$ \\
\hline
\end{tabular}

\section{$\mathrm{N}$-acetylalanine aminopeptidase activity in human lung cells}

Alveolar macrophages and human lung fibroblasts (tabl. 2) contained about 10 times more activity than erythrocytes. We found even more activity in human lung tumour cells (tab. 2). In our laboratory we culture human lung tumour cells routinely. At present, we have two cell lines (HS 24 and HS 57), which have been growing for months. Another cell line (HS 34) died after one month, and three other samples (HS 37, HS 38, and HS 40) lived only a few days. The amount of $\mathrm{N}$-acetylalanine aminopeptidase in these cells ranged from $5.6 \mathrm{nU} /$ cell to $29 \mathrm{nU} /$ cell. The reason for this difference of morie than one order of 


\section{SCHON GWWSST?}

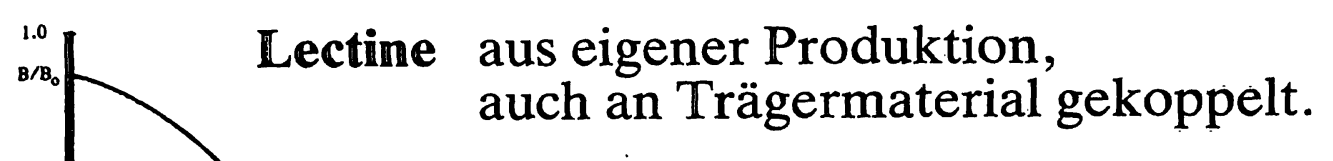

Antiseren aus monoclonaler und/oder herkömmlicher Gewinnung stehen in bewährter Qualität auch konjugiert, aus einer Hand in großer Auswahl zur Verfügung.

Ein gut sortiertes Lager macht schnellste Lieferung zu wettbewerbsfähigen Preisen möglich.

Bezug und weitere Information

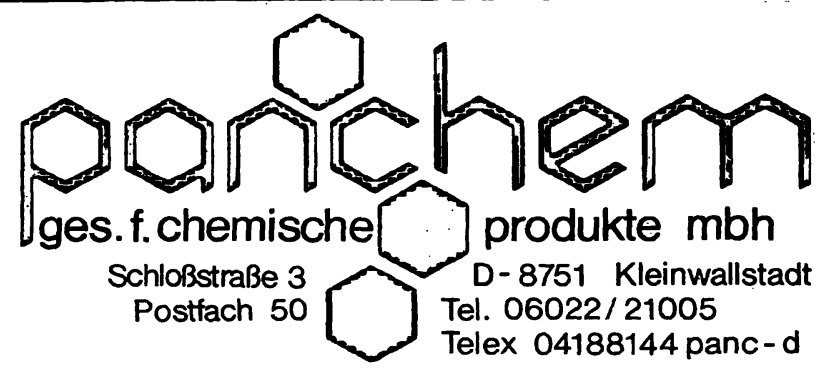

Trace Element

Analytical Chemistry in Nhedicine and Biology Volunge 3

Proceedings of the Third International

Workshop - Neuherberg,

Federal Republic of Germany, April 1984

\section{Editors P. Brätter, P. Schramel}

1984. $17 \mathrm{~cm} \times 24 \mathrm{~cm}$. XVI, 763 pages. Numerous illustrations.

Hardcover. DM 240,-; approx. US \$80.00 ISBN 3110098210

The proceedings contained in this volume are specifically concerned with new developments in the field of the essential trace elements selenium, zinc and manganese as well as with.current problems in analysis, nutrition and medicine. The actual state of knowledge about other recently recognized essential trace elements also played a dominant role.

Price is subject to change without notice

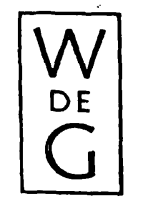

Walter de Gruyter - Berlin - New York

Verlag Walter de Gruyter \& Co., Genthiner Str. 13, D-1000 Berlin 30, Tel.: (030) 26005-0, Telex 184027 Walter de Gruyter, Inc., 200 Saw Mill River Road, Hawthorne, N. Y. 10532, Tel.: (914) 747-0110, Telex 646677 
magnitude between these basically similar cells is not yet understood, but it could be caused by a different tumour history and/or by the cell division phase. As we collected the cells from the culture flasks we did not check the relative proportions of S-, G- and Mphase cells (16).

Tab. 2. N-acetylalanine aminopeptidase activity in human lung cells. Values are from one preparation, because the cells were only once available or cultured. In the latter case it was impossible to get the same type of cells again.

\begin{tabular}{lcc}
\hline & $\begin{array}{l}\text { No. of } \\
\text { viable cells } \\
\left(10^{6}\right)\end{array}$ & $\begin{array}{l}\text { Catalytic } \\
\text { concentration } \\
\text { (nU/cell) }\end{array}$ \\
\hline Alveolar macrophages & 5.8 & 3.7 \\
Fibroblasts & 20 & 6.7 \\
Tumour HS 24 & 14 & 16 \\
Tumour HS 34 & 8.5 & 10 \\
Tumour HS 37 & 3.5 & 5.6 \\
Tumour HS 38 & 0.6 & 13 \\
Tumour HS 40 & 5.3 & 8 \\
Tumour HS 57 & 32 & 2.9 \\
Tumour HS 105 & 3 & 16 \\
\hline
\end{tabular}

$\mathrm{N}$-acetylalanine aminopeptidase activity in cells from other sources

$\mathrm{N}$-acetylalanine aminopeptidase activity was additionally determined in cells from human umbilical vein, from mice and rats, and from hog and bovine lungs (tab. 3). The lowest amounts in these cells were found in bovine endothelial cells ( $1 \mathrm{nU} /$ cell), and the highest activity was found the high-metastasizing rat cell line B Sp 73 ASML (35 nU/cell).

Tab. 3. $\mathrm{N}$-acetylalanine aminopeptidase activity in cells from different sources. for the reasons mentioned in the legend of table 2, values are from one preparation.

\begin{tabular}{lcc}
\hline & $\begin{array}{l}\text { No. of } \\
\text { viable cells } \\
\left(10^{6}\right)\end{array}$ & $\begin{array}{l}\text { Catalytic } \\
\text { Concentration } \\
\text { (nU/cell) }\end{array}$ \\
\hline Rat B Sp 73 AS cells & 200 & 9.8 \\
Rat B Sp 73 ASML cells & 30 & 35 \\
Mice Leydig cells & 1 & 1.6 \\
Hog lung endothelial cells & 12 & 3.7 \\
Bovine lung endothelial cells & 100 & 1 \\
Human umbilical & 5.5 & 9.8 \\
endothelial cells & & \\
\hline
\end{tabular}

\section{References}

1. Yoshida, A. \& Lin, M. (1972) J. Biol. Chem. 247, 952-957.

2. Witheiler, J. \& Wilson, D. B. (1972) J. Biol. Chem. 247, 2217-2221.

3. Tsunasawa, S., Narita, K. \& Ogata, V. (1975) J. Biochem. $77,89-102$.
$\mathrm{N}$-acetylalanine aminopeptidase activity in human plasma

In contradiction of Unger \& Struck (17) we could not detect any $\mathrm{N}$-acetylalanine aminopeptidase activity in human plasma. To clarify this point we checked plasma samples withdrawn from the same donor into different tubes. One tube contained no beads and another contained some beads for a better separation between plasma and blood cells. $\mathrm{N}$-acetylalanine aminopeptidase activity was found only in the latter samples; obviously some erythrocytes were lysed and the enzyme was released into the plasma.

\section{Discussion}

All cells we have checked so far contained $\mathrm{N}$-acetylalanine aminopeptidase activity. Erythrocytes showed the lowest activity per cell, but considering the abundance of red blood cells, their entire activity is remarkable high and could be of physiological importance. Unfortunately, the physiological role of $\mathrm{N}$ acetylalanine aminopeptidase is not known, but there are some speculations about the function of $\mathrm{N}$-acylamino acyl-peptide hydrolases in protein biosynthesis $(10,18)$ and in intracellular protein turnover $(8)$.

In all human lung cancer cells, in human umbilical endothelial cells, and in the rat tumour cell lines AS and ASML, the $\mathrm{N}$-acetylalanine aminopeptidase activity was quite high. In the case of HS 24 and HS 57 we measured the activity over a period of time (13). The amount of $\mathrm{N}$-acetylalanine aminopeptidase went up and down, but the activity was always higher than in all other cells. Whether these high values indicate a tumour-specific characteristic or a normal characteristic of growing cells, can only be judged when we can successfully culture normal human lung cells. However, the conclusion that the enzyme is a normal characteristic of growing cells is favored by the high activity in human umbilical endothelial cells.

\section{Acknowledgement}

The endothelial cell isolation method was recommended to us by Dr. Thilo-Körner, Gießen. This work was supported by the Tumorzentrum Heidelberg/Mannheim.

4. Lorentz, K., Petersen, S. \& Ritter, U. (1975) Z. Klin. Chem. Klin. Biochem. 13, 45-48.

5. Tsunasawa, S. \& Narita, K. (1976) Methods Enzymol. 45, $552-561$.

6. Gade, W. \& Brown, J. L. (1978) J. Biol. Chem. 253, 5012-5018. 
7. Suda, H., Yamamoto, K. \& Umezawa, H. (1980) Biochim. Biophys. Acta 616, 60-67.

8. Schoenberger, O. L. \& Tschesche, H. (1981) Hoppe-Seyler's Z. Physiol. Chem. 362, 865-873.

9. Marks, N., Lo, E.-S., Stern, F. \& Danho, W. (1983) J. Neurochem. 41, $201-208$.

10. Jones, W. M. \& Manning, J. M. (1985) Biochem. Biophys. Res. Commun. 126, 933-940.

11. Aulenbacher, P., Werling, H.-O., Paweletz, N. \& Spiess, E. (1984) Anticancer Res. 4, 75-82.

12. Nees, S. \& Fink, W. (1984) Labor Praxis 1314-1317.

13. Schoenberger, O. L., Ebert, W. \& Drings, P. in preparation.
14. Wachsmuth, E. D., Fritže, I. \& Pfleiderer, G. (1966) Biochemistry $5,169-174$.

15. Ehrengruber, H. (1978) in Klinische Chemie, 4th edn. (Richterich, R. \& Colombo, J.P., eds.) pp. 39-40, S. Karger, Basel.

16. Stẹin, G. \& Bàseraga, R. (1972) Adv. Cancer Res. 5, $287-330$.

17. Unger, T. \& Struck, H. (1977) 'Ćlin. Chim. Acta 78, $113-120$.

18. Narita, K., Tsuchida, I., Tsunasawa, S. \& Ogata, K. (1969) Biochem. Biophys. Res. 'Commun. 37, 327-332.

Dr. Oeyvind L. Schoenberger

Krankenhaus Rohrbach

Klinik für Thoraxerkrankungen

Amalienstr. 5

D-6900 Heidelberg 1 